ISSN 1392-3196 / e-ISSN 2335-8947

Zemdirbyste-Agriculture, vol. 103, No. 1 (2016), p. 29-34

DOI 10.13080/z-a.2016.103.004

\title{
The safener effect of chiral derivatives of 3-dichloroacetyl oxazolidine against haloxyfop-P-methyl-induced toxicity in maize
}

\author{
Fei YE, Hai-Feng CAO, Ying FU, Li-Xia ZHAO, Shuang GAO \\ College of Science, Northeast Agricultural University \\ Harbin, Heilongjiang, P. R. China \\ E-mail: zhaolixia@neau.edu.cn
}

\begin{abstract}
Herbicide safener, a diverse group of chemicals, is an important tool used to protect plants from herbicidal injury. With the aim of decreasing drift injury of haloxyfop-P-methyl to sensitive plants, the protective effect of four safeners (R-28725, 3-dichloroacetyl oxazolidine and its two optical isomers) was evaluated. Physiological and biochemical tests were conducted under laboratory conditions in Northeast Agricultural University, China, by using seed treatment with safener and soil treatment with haloxyfop-P-methyl, respectively. The maize seeds treated with these safeners were safe from haloxyfop-P-methyl treatment. A positive correlation between growth level and endogenous glutathione (GSH) content, glutathione S-transferases (GST) activity was observed in this research. Enhancement of GSH content, GST activity and affinity of GST to 1-chloro-2,4-dinitrobenzene (CDNB) in maize treated by R-28725 was maximum. However, the detoxification of herbicide was not accompanied by the increase of acetyl-CoA-carboxylase (ACC) activity in maize.
\end{abstract}

Key words: 3-dichloroacetyl oxazolidine, glutathione S-transferases activity, glutathione S-transferases affinity, haloxyfop-P-methyl.

\section{Introduction}

Haloxyfop-P-methyl [methyl(R)-2-[4-(3-chloro5-trifluoromethyl-2-pyridyloxy)phenoxy] propionate], R-enantiomerofhaloxyfop, isanaryloxyphenoxypropionic acid herbicide controlling annual and perennial weeds in dicotyledoneous crops (Bijanzadeh et al., 2010; Hammami et al., 2014). Haloxyfop-P-methyl controls weeds by competitive binding to acetyl-CoA-carboxylase (ACC), which is an important enzyme in the biosynthesis of fatty acids (Hijano et al., 2013). However, application of haloxyfop-P-methyl at recommended dose may cause injury to some soybean cultivars (Parsa et al., 2013). It also has been reported that strong inhibition of biosynthesis of fatty acids was observed in wheat and maize treated by haloxyfop (Banas et al., 2012).

Herbicide safeners, also referred to as herbicide antidotes, are a diverse group of chemicals that enhance the detoxification ability of crops to herbicide but without decrease in herbicidal activity (Kraehmer et al., 2014; Elmore et al., 2015). In the late 1940s, the phenomenon of herbicide safener was discovered serendipitously by Otto Hoffman. The products of safener were subsequently commercialized by agrochemical companies intensively in late $20^{\text {th }}$ century (Jablonkai, 2013). Nevertheless intensive research has been conducted in recent years; the exact mechanism of safener is incompletely understood (Hull et al., 2008). Research on safeners previously focused on the structure-activity relationship of safener and the actions of safener on the detoxification process of herbicide in plants (Fu et al., 2012; Cataneo et al., 2013). It is generally believed that safeners enhance the expression of plant defense and detoxification genes such as glutathione S-transferases (GST), cytochrome $\mathrm{P} 450$, and endogenous glutathione (GSH) involved in exogenous compounds metabolism (Matola, Jablonkai, 2007; Del Buono, Ioli, 2011). It has been observed previously that GSH-mediated detoxification induced by safener was involved in the metabolic detoxification of herbicides (Riechers et al., 2010). However, to the best of our knowledge, no safener has been developed for haloxyfop-P-methyl so far.

R-28725 (3-dichloroacetyl-2,2-dimethyl-1,3oxazolidine) has been proven effective in reducing herbicidal injury from ALS (acetolactate synthase)inhibitor herbicides (Zhao et al., 2014). Its analogue, 3-dichloroacetyl-2,2-dimethyl-4-ethyl-1,3-oxazolidine, is a chiral molecule that has given rise to two optical isomers. With the aim of decreasing the herbicidal injury, bioactivity of optical isomers and racemate of 3-dichloroacetyl-2,2-dimethyl-4-ethyl-1,3-oxazolidine and R-28725 were accessed. In addition, this study was conducted to assess the protective ability of these compounds related to detoxification of herbicide, namely, GSH, GST and ACC activity. 


\section{Materials and methods}

Materials and chemical reagents. The tested soil was collected from Horticulture Station, Northeast Agricultural University, Harbin, China. It is classified as Phaeozem (PH) according to FAO (WRB, 2014), with a $\mathrm{pH}$ of 7.37. The seedlings of maize (Zea mays L.) cultivar 'Dongnong 253' were germinated and grown in a growth chamber at the Pesticide Chemistry Laboratory, Northeast Agricultural University during the period of 2012-2014. Haloxyfop-P-methyl (99.5\%, powder) was obtained from Aladdin Chemistry (Shanghai, China). R-28725, 3-dichloroacetyl-2,2-dimethyl-4-ethyl-1,3oxazolidine and its two optical isomers were synthesized in our laboratories (99.0\%) (Table 1, Fig. 1).

Table 1. Chemical name of safeners used for the test

\begin{tabular}{cc}
\hline Safener & Chemical name \\
\hline R-28725 & 3-dichloroacetyl-2,2-dimethyl-1,3-oxazolidine \\
R-isomer & (R)-3-dichloroacetyl-2,2-dimethyl-4-ethyl-1,3-oxazolidine \\
S-isomer & (S)-3-dichloroacetyl-2,2-dimethyl-4-ethyl-1,3-oxazolidine \\
Racemate & (RS)-3-dichloroacetyl-2,2-dimethyl-4-ethyl-1,3-oxazolidine \\
\hline
\end{tabular}

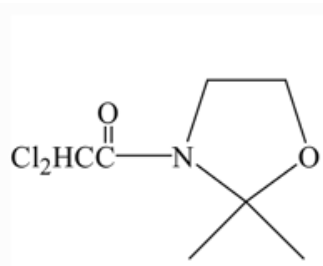

R-28725

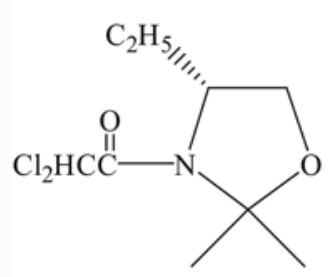

R-isomer

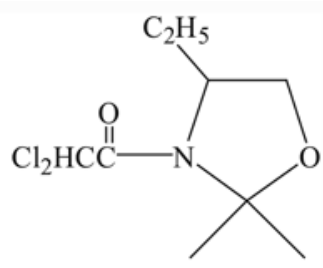

Racemate

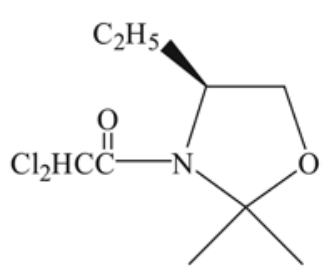

S-isomer
Figure 1. Structure of safeners used for the test
Growth conditions. Seeds of maize were soaked in solutions of safeners $\left(0,1,5,10,25,50\right.$ and $\left.100 \mathrm{mg} \mathrm{kg}^{-1}\right)$ for 12 hours; the control was soaked in water. Then the seeds were germinated in dishes in a growth chamber for 24 hours. After that the seeds were sown in soil with a depth of $1 \mathrm{~cm}$ in paper-cups $(10 \times 15 \mathrm{~cm}), 7$ seeds per cup. The paper-cups contained soil added with haloxyfop-Pmethyl $\left(6 \mu \mathrm{g} \mathrm{kg}^{-1}\right)$ with a depth of $13 \mathrm{~cm}$, the seedlings were incubated in a growth chamber with a photoperiod of $12 \mathrm{~h}$ light and $12 \mathrm{~h}$ dark, $26.5 \pm 1{ }^{\circ} \mathrm{C}$ temperature, $75 \%$ relative humidity. Each treatment was replicated three times.

The samples of maize plants were washed and collected 7 days after treatment. The recovery rate of growth index (plant height, root length, fresh weight of shoot, fresh weight of root) of maize was measured. Recovery rate of growth index was calculated according to the following formula:

$$
\text { Recovery rate }(\%)=\frac{\text { growth index of maize treated by safener and herbicide }- \text { growth index of maize treated by herbicide }}{\text { growth index of maize untreated }- \text { growth index of maize treated by herbicide }}
$$

where safener is R-28725, 3-dichloroacetyl2,2-dimethyl-4-ethyl-1,3-oxazolidine and its two optical isomers, respectively, and herbicide is haloxyfop-Pmethyl. The recovery rate of growth index was calculated respectively and expressed as percent.

The shoot and root tissues of maize were stored in a refrigerator for biological activity assays.

Determination of endogenous glutathione (GSH) content. GSH content was measured by UVvisible spectrophotomer as described previously (Ismaiel, Papenbrock, 2014). To perform the determination, 5,5'-dithiobis(2-nitrobenzoic acid) (DTNB) was used as chromogenic agent, absorbance data collected at 412 $\mathrm{nm}$, and GSH content were calculated by comparing with standard working curve.

Determination of glutathione S-transferases (GST) activity. The extraction and assay of GST were performed as described by Matola and Jablonkai (2007). The GST activity was obtained by measuring the amount of conjugate constituted from GSH and substrate 1-chloro-2,4-dinitrobenzene (CDNB) and expressed as amount of conjugate per minute per mg of protein $(\mu \mathrm{mol}$ $\mathrm{min}^{-1} \mathrm{mg}^{-1}$ protein).

To determine the GST activity in vitro (GST activity against haloxyfop-P-methyl in this study), the amount of haloxyfop-P-methyl was determined by high performance liquid chromatography (HPLC) as described previously (Scarponi et al., 2006; Li et al., 2012). GST enzyme was extracted from root of maize, and added with glutathione and haloxyfop-P-methyl solution. After cultivation for 2 hours, residues of haloxyfop-P-methyl in this mixture were determined by HPLC. The GST activity in vitro was expressed as amount of haloxyfopP-methyl consumed per minute per mg of enzyme (nmol $\mathrm{min}^{-1} \mathrm{mg}^{-1}$ protein).

Determination of kinetic parameters of GST $(C D N B)$. The procedure described by Scarponi et al. (2006) was followed for measuring kinetic parameters of GST with modification. The kinetic parameters were determined by measuring GST activity over a range of CDNB concentrations $(0.13-4.14 \mathrm{mM})$ and at a single GSH concentration of $5 \mathrm{mM}$.

Determination of acetyl-CoA-carboxylase (ACC) activity. To investigate the effect of safener on target enzyme, ACC activity was determined as described previously (Islam et al., 2014). ACC activity was expressed as amount of malonyl-CoA per min per $\mathrm{mg}$ of enzyme (nmol $\mathrm{min}^{-1} \mathrm{mg}^{-1}$ protein).

Statistical analysis. Software Statistical Product and Service Solutions (SPSS 16.0) was used 
to determine statistical significance at $95 \%$ confidence level $(p<0.05)$. The data were expressed as mean \pm standard deviation $(\mathrm{n}=3)$.

\section{Results}

Growth index of maize. A significant reduction of growth index of maize was observed when haloxyfopP-methyl was applied in soil. Haloxyfop-P-methyl applied at $6 \mu \mathrm{g} \mathrm{kg}^{-1}$ in soil caused 20.69, 27.62, 28.35 and $32.21 \%$ injury to plant height, root length, fresh weight of shoot, and fresh weight of root of maize, respectively.
Dose response curves of safeners (R-28725, R-isomer, S-isomer and Racemate) were prepared to determine the appropriate concentration of safeners offering maximum protection. Figure 2 shows the recovery rate of growth index of maize treated with haloxyfop-Pmethyl and four safeners. Significant differences were observed for recovery rate at different concentrations of safener in this study. The optimum concentration for R-28725, R-isomer, S-isomer and Racemate were 5, 25,100 and $100 \mathrm{mg} \mathrm{kg}^{-1}$, respectively. This observation clearly indicates that appropriate concentration of safener significantly decreases herbicidal injury from haloxyfop-

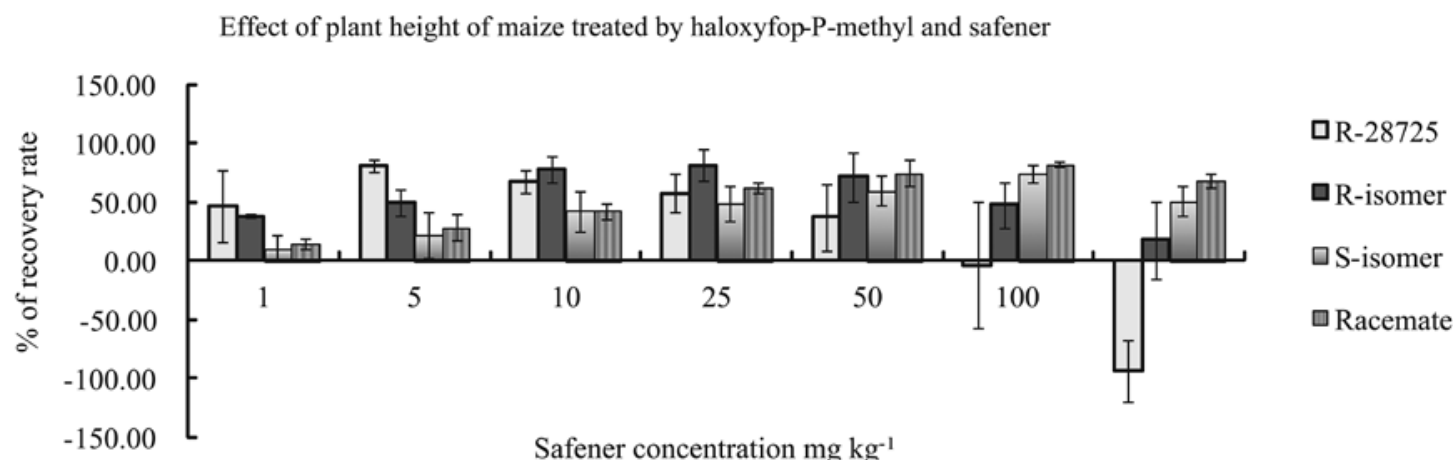

Effect of root length of maize treated by haloxyfop-P-methyl and safener

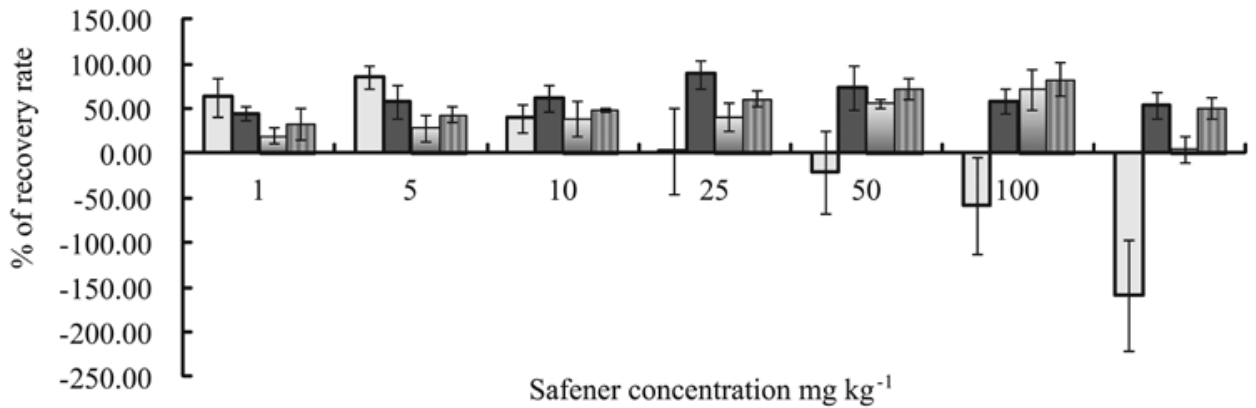

Safener concentration $\mathrm{mg} \mathrm{kg}^{-1}$
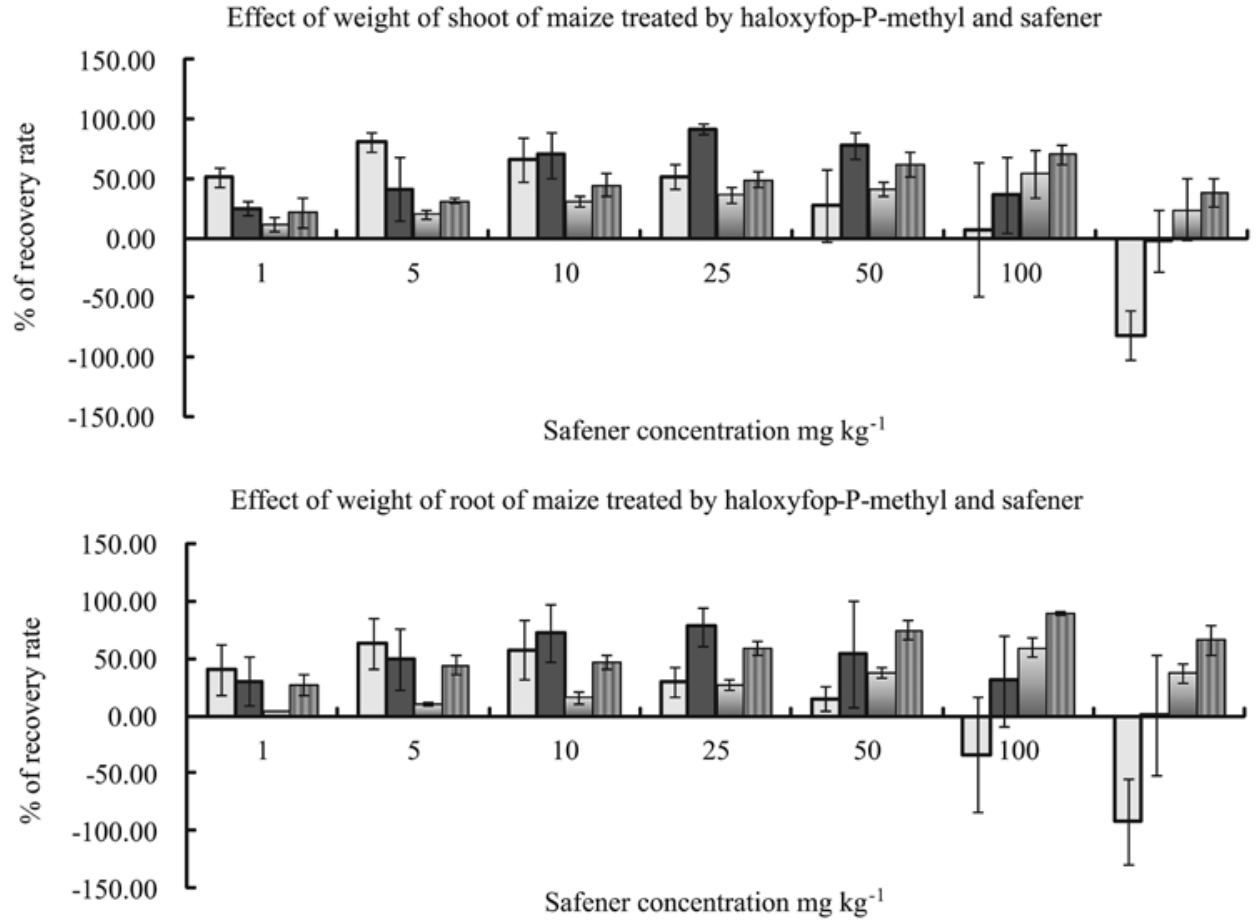

Figure 2. Recovery rate of growth level of maize treated with haloxyfop-P-methyl and safener 
P-methyl. However, the increase in growth index of maize treated with R-28725 and haloxyfop-P-methyl started from $1 \mathrm{mg} \mathrm{kg}^{-1}$ and continued till $50 \mathrm{mg} \mathrm{kg}^{-1}$, and thereafter it dropped rapidly. Optimum concentration for each safener was then applied to maize for subsequent testing.

Glutathione (GSH) content. It has been reported that safeners could increase the conjugation of xenobiotic compounds with GSH through elevating the level of GSH in plant (Requejo, Tena, 2012). Therefore, GSH content in plants treated with safener was an important index to access the protective ability of safener. In this evaluation, haloxyfop-P-methyl applied in soil at $6 \mu \mathrm{g} \mathrm{kg}^{-1}$ caused a slight increase in GSH content in maize (Table 2). As response to treatment with safener, the content of GSH in maize increased significantly. The increase of GSH induced by safener has also been reported previously (Jablonkai, 2013).

Table 2. Effect of safeners and haloxyfop-P-methyl on endogenous glutathione (GSH) content ( $\left.\mu \mathrm{g} \mathrm{g}^{-1}\right)$ in maize

\begin{tabular}{ccc}
\hline Treatment & In root & In shoot \\
\hline Control & $5.02 \pm 0.229 \mathrm{~d}$ & $11.45 \pm 0.559 \mathrm{e}$ \\
Haloxyfop-P-methyl & $6.48 \pm 0.462 \mathrm{c}$ & $15.03 \pm 0.534 \mathrm{~d}$ \\
R-isomer + haloxyfop-P-methyl & $10.47 \pm 0.571 \mathrm{a}$ & $20.13 \pm 1.064 \mathrm{a}$ \\
S-isomer + haloxyfop-P-methyl & $8.44 \pm 0.483 \mathrm{~b}$ & $16.84 \pm 0.469 \mathrm{c}$ \\
Racemate + haloxyfop-P-methyl & $10.85 \pm 0.168 \mathrm{a}$ & $18.33 \pm 1.067 \mathrm{~b}$ \\
R-28725 + haloxyfop-P-methyl & $10.88 \pm 0.365 \mathrm{a}$ & $20.08 \pm 0.807 \mathrm{a}$ \\
\hline
\end{tabular}

Note. Mean \pm standard deviation; values sharing the same letters differ non-significantly $(P>0.05)$; the values correspond to averages of three replicates.

Glutathione S-transferases (GST) activity. The role of GST is essential for detoxification ability of safener, depending on the action mechanism of safener. To access the functional role of GST in detoxification process, the effect of safener and haloxyfop-P-methyl on GST activity of maize was investigated in this study
(Table 3). Combined application of haloxyfop-P-methyl and safener significantly increased the GST activity in vivo of maize. In a like manner, the GST activity in vitro of maize treated by R-isomer or R-28725 also showed a significant increase. These findings are in agreement with earlier reports (Benekos et al., 2010).

Table 3. Effect of safeners and haloxyfop-P-methyl on activity of glutathione S-transferases (GST) in maize

\begin{tabular}{cccc}
\hline Treatment & $\begin{array}{c}\text { in vivo } \\
\mu \text { mol } \mathrm{min}^{-1} \mathrm{mg}^{-1} \text { protein }\end{array}$ & Treatment & $\begin{array}{c}\text { in vitro } \\
\mathrm{nmol} \mathrm{min}^{-1} \mathrm{mg}^{-1} \mathrm{protein}^{-}\end{array}$ \\
\hline Control & $3.10 \pm 0.215 \mathrm{e}$ & Control & $0.557 \pm 0.0324 \mathrm{c}$ \\
Haloxyfop-P-methyl & $4.10 \pm 0.229 \mathrm{~d}$ & Haloxyfop-P-methyl & $0.207 \pm 0.0316 \mathrm{~d}$ \\
R-isomer + haloxyfop-P-methyl & $8.68 \pm 0.558 \mathrm{~b}$ & R-isomer & $1.809 \pm 0.2505 \mathrm{a}$ \\
S-isomer + haloxyfop-P-methyl & $6.47 \pm 0.529 \mathrm{c}$ & S-isomer & $0.681 \pm 0.0551 \mathrm{bc}$ \\
Racemate + haloxyfop-P-methyl & $8.58 \pm 0.325 \mathrm{~b}$ & Racemate & $0.857 \pm 0.0586 \mathrm{~b}$ \\
R-28725 + haloxyfop-P-methyl & $9.76 \pm 0.550 \mathrm{a}$ & R-28725 & $2.015 \pm 0.1585 \mathrm{a}$ \\
\hline
\end{tabular}

Explanation under Table 2

Kinetic parameters of GST. To better understand the effect of safener on GST, the kinetic parameters of GST were determined for further research (Table 4). The maximum rate $\left(V_{\max }\right)$ and Michaelis constant $\left(K_{\mathrm{M}}\right)$ (the substrate concentration which results in one-half of the maximum velocity) of GST were determined by linear regression of a double reciprocal plot (Scarponi et al., 2006). $V_{\max }$ of GST for maize treated by R-28725 was significantly higher as compared to other safeners. At the same time, a significant decrease of $K_{\mathrm{M}}$ of GST for maize treated by R-28725 was observed, indicating the strong inducement of GST caused by R-28725. Other safeners also induced the affinity of GST to substrate in the conjugated reaction. It was similar with the results of GSH content and GST activity.

Table 4. Effect of safeners and haloxyfop-P-methyl on kinetic parameters of maize glutathione S-transferases (GST)

\begin{tabular}{ccc}
\hline Treatment & $\begin{array}{c}V_{\max } \\
\mathrm{nmol} \mathrm{min}^{-1} \mathrm{mg}^{-1} \text { protein }\end{array}$ & $\begin{array}{c}K_{\mathrm{M}} \\
\mathrm{mmol} \mathrm{L}^{-1}\end{array}$ \\
\hline Control & $0.790 \pm 0.0300 \mathrm{e}$ & $1.950 \pm 0.0557 \mathrm{~b}$ \\
Haloxyfop-P-methyl & $0.623 \pm 0.0732 \mathrm{f}$ & $3.627 \pm 0.1069 \mathrm{a}$ \\
R-isomer & $1.437 \pm 0.0231 \mathrm{~b}$ & $1.320 \pm 0.0100 \mathrm{~d}$ \\
S-isomer & $0.913 \pm 0.0666 \mathrm{~d}$ & $1.673 \pm 0.0569 \mathrm{c}$ \\
Racemate & $1.090 \pm 0.0346 \mathrm{c}$ & $1.570 \pm 0.0173 \mathrm{c}$ \\
R-28725 & $1.597 \pm 0.0907 \mathrm{a}$ & $1.167 \pm 0.1443 \mathrm{~d}$ \\
\hline
\end{tabular}

Explanation under Table 2

Acetyl-CoA-carboxylase (ACC) activity. Safener protects crops by depressing the herbicide levels reaching the targeted site (Rushing et al., 2013). For that reason, ACC activity is critical for maize to decrease the injury caused by haloxyfop-P-methyl. Data obtained in this study showed that ACC activity of maize was significantly inhibited by haloxyfop-P-methyl (Table 5). However, it was noteworthy that no influence was observed in response to safener application. 
Table 5. Effect of safeners and haloxyfop-P-methyl on acetyl-CoA-carboxylase (ACC) activity of maize

\begin{tabular}{|c|c|}
\hline Treatment & $\begin{array}{c}\text { ACC activity } \\
\text { nmol min } \mathrm{mg}^{-1} \text { protein }\end{array}$ \\
\hline Control & $5.14 \pm 0.561 \mathrm{a}$ \\
\hline Haloxyfop-P-methyl & $2.35 \pm 0.135 b$ \\
\hline $\mathrm{R}$-isomer + haloxyfop-P-methyl & $2.67 \pm 0.250 \mathrm{~b}$ \\
\hline S-isomer + haloxyfop-P-methyl & $2.56 \pm 0.379 \mathrm{~b}$ \\
\hline Racemate + haloxyfop-P-methyl & $2.30 \pm 0.261 \mathrm{~b}$ \\
\hline R-28725 + haloxyfop-P-methyl & $2.74 \pm 0.314 b$ \\
\hline
\end{tabular}

Explanation under Table 2

\section{Discussion}

While herbicide contributes to improving crop yield, it can also pose a risk to the plants which are sensitive to them (Jursik et al., 2010). The use of herbicide at present has resulted in increased incidence of herbicidal injury (Grey et al., 2012; Cieslik et al., 2014). For that reason, it becomes essential to develop effective safeners. Even though, no safener has been developed to protect sensitive crops from haloxyfop-P-methyl. In order to develop safener for haloxyfop-P-methyl, the protective effects of four safeners were evaluated in our laboratory. The results conclusively demonstrated that the maize plants injured by haloxyfop-P-methyl were effectively protected by these safeners. The maize seeds that had been soaked in solution of safener were safe from haloxyfop-P-methyl treatment.

For evaluation of the enhancement of detoxification of maize, induced by safeners, the GSH content, GST activity, and ACC activity of maize treated by haloxyfop-P-methyl and safener were investigated. The results indicate that these safeners caused enhancement of GSH content, GST activity and affinity of GST enzyme to substrate. These results are in agreement with previous studies, according to which safeners significantly change the affinity of GST to substrate of conjugation reaction (Scarponi et al., 2006). It has also been observed that high GST activity may contribute to the tolerance of rice to glyphosate and chlorsulfuron ( $\mathrm{Hu}, 2014)$. A positive correlation between growth level and GSH content, GST activity has been observed in this research. Enhancement of GSH content, GST activity and affinity of GST to CDNB in maize treated by R-28725 was maximum. It was observed that the order of protective ability of safeners was as follows: R-28725 $>$ R-isomer $>$ Racemate $>$ S-isomer. Based on the results obtained in this study, it seems that these safeners induce the conjugation of herbicide with GSH catalyzed by GST to some extent. Consistent with this notion, it has been shown that some major crops are able to conjugate herbicides rapidly by different pathways (Cummins et al., 2011). However, it should be noted that there is no increase of ACC activity in response to safener application. Another assumption made above is that the detoxification of herbicide was not always accompanied by the release of target enzyme in plants.

\section{Conclusions}

1. Four safeners - R-28725, 3-dichloroacetyl oxazolidine and its two optical isomers - present protective ability against injury caused to maize by haloxyfop-P-methyl.
2. There are indications that the inducement of endogenous glutathione (GSH) content and glutathione S-transferases (GST) activity were not accompanied by the release of acetyl-CoA-carboxylase (ACC) activity in maize treated with haloxyfop-P-methyl and safener. This might suggest that the detoxification process may not always be accompanied by the induction of target enzyme.

\section{Acknowledgements}

This work was supported by the National Nature Science Foundation of China (No. 31401787 , 31572042), the China Postdoctoral Science Foundation (No. 2014M551208), the Natural Science Foundation of Heilongjiang Province of China (No. C2015014), the Science and Technology Research Project of Heilongjiang Education Department (No. 12541029), and the "Young Talents" Project of Northeast Agricultural University (No. 14QC38).

Received 08092015

Accepted 20012016

\section{References}

Banas W., Furmanek T., Banas A. 2012. Effect of haloxyfop and cerulenin on de novo biosynthesis of lipids in roots of wheat and maize. Acta Biochemica Polonica, 59 (4): 567-573

Benekos K., Kissoudis C., Nianiou-Obeidat I., Labrou N., Madesis P., Kalamaki M., Makris A., Tsaftaris A. 2010. Overexpression of a specific soybean GmGSTU4 isoenzyme improves diphenyl ether and chloroacetanilide herbicide tolerance of transgenic tobacco plants. Journal of Biotechnology, 150 (1): 195-201 http://dx.doi.org/10.1016/j.jbiotec.2010.07.011

Bijanzadeh E., Ghadiri H., Behpouri A. 2010. Effect of trifluralin, pronamide, haloxyfop-p methyl, propaquizafop, and isoxaben on weed control and oilseed rape yield in Iran. Cron Protection, 29 (8): 808-812 http://dx.doi.org/10.1016/j.cropro.2010.04.015

Cataneo A. C., Ferreira L. C., Mischan M. M., Velini E. D., Corniani N., Cerdeira A. L. 2013. Mefenpyr-diethyl action on fenoxaprop-P-ethyl detoxification in wheat varieties. Planta Daninha, 31 (2): 387-393 http://dx.doi.org/10.1590/S0100-83582013000200016

Cieslik L. F., Vidal R. A., Trezzi M. M. 2014. Fomesafen toxicity to bean plants as a function of the time of application and herbicide dose. Acta Scientiarum: Agronomy, 36 (3): 329-334 http://dx.doi.org/10.4025/actasciagron.v36i3.17630

Cummins I., Dixon D. P., Freitag-Pohl S., Skipsey M., Edwards R. 2011. Multiple roles for plant glutathione transferases in xenobiotic detoxification. Drug Metabolism Reviews, 43 (2): 266-280 http://dx.doi.org/10.3109/03602532.2011.552910

Del Buono D., Ioli G. 2011. Glutathione S-transferases of Italian ryegrass (Lolium multiflorum): activity toward some chemicals, safener modulation and persistence of atrazine and fluorodifen in the shoots. Journal of Agricultural and Food Chemistry, 59 (4): 1324-1329 http://dx.doi.org/10.1021/jf1043713

Elmore M. '., Brosnan J. I., Armel G. R., Vargas J. J., Breeden G. K. 2015 Influence of herbicide safeners on creeping bentgrass (Agrostis stolonifera) tolerance to herbicides. Weed Technology, 29 (3): 550-560 http://dx.doi.org/10.1614/WT-D-14-00045.1

Fu Y., Li H. T., Ye F., Gao S., Zhao Q. S. 2012. Quantitative structure activity relationship study on a novel series of $\mathrm{N}$-dichloroacetyl oxazolidine herbicide safeners. Indian Journal of Heterocyclic Chemistry, 21 (4): 375-380

Grey T. L., Braxton L. B., Richburg J. S. 2012. Effect of wheat herbicide carryover on double-crop cotton and soybean. Weed Technology. 26 (2): 207-212 http://dx.doi.org/10.1614/WT-D-11-00143.1 
Hammami H., Aliverdi A., Parsa M. 2014. Effectiveness of clodinafop-propargyl, haloxyfop-p-methyl and difenzoquatmethyl-sulfate plus adigor (R) and propel (TM) adjuvants in controlling avena ludoviciana durieu. Journal of Agricultural Science and Technology, 16 (2): 291-299

Hijano N., Monquero P. A., Munhoz W. S., Gusmão M. R. 2013. Herbicide selectivity in alfalfa crops. Planta Daninha, 31 (4): 903-918 http://dx.doi.org/10.1590/S0100-83582013000400017

$\mathrm{Hu}$ T. Z. 2014. A glutathione S-transferase confers herbicide tolerance in rice. Crop Breeding and Applied Biotechnology, 14 (2): $76-81$ http://dx.doi.org/10.1590/1984-70332014v14n2a14

Hull R., Marshall R., Tatnell l., Moss S. R. 2008. Herbicideresistance to mesosulfuron + iodosulfuron on Alopecurus myosuroides (black-grass). Communications in Agricultural and Applied Biological Sciences, 73 (4): 903-912

Islam F., Yasmeen T., Riaz M., Arif M. S., Ali S., Raza S. H. 2014. Proteus mirabilis alleviates zinc toxicity by preventing oxidative stress in maize (Zea mays) plants. Ecotoxicology and Environmental Safetv. 110 (10): 143-152 http://dx.doi.org/10.1016/j.ecoenv.2014.08.020

Ismaiel A. A., Papenbrock J. 2014. The effects of patulin from Penicillium vulpinum on seedling growth, root tip ultrastructure and glutathione content of maize. European Journal of Plant Pathology, 139 (3): 497-509 http://dx.doi.org/10.1007/s10658-014-0406-9

Jablonkai I. 2013. Herbicide safeners: effective tools to improve herbicide selectivity. <http://dx.doi.org/10.5772/55168> [accessed 1712 2015]

Jursik M., Soukup J., Holec J. 2010. Herbicide mode of actions and symptoms of plant injury by herbicides: introduction to herbicide mode of action problems. Listy cukrovarnicke a reparske, 126 (1): 14-16 (in Czech)

Kraehmer H., Laber B., Rosinger C., Schulz A. 2014. Herbicides as weed control agents: state of the art: I. Weed control research and safener technology: the path to modern agriculture. Plant Physiology, 166 (3): 1119-1131 http://dx.doi.org/10.1104/pp.114.241901

Li S. Q., Gao P., Zhang J. H., Li Y. B., Peng B., Gao H. X., Zhou, W. F. 2012. Sequential dispersive liquid-liquid microextraction for the determination of aryloxyphenoxypropionate herbicides in water. Journal of Separation Science, 35 (23): 3389-3395 http://dx.doi.org/10.1002/jssc. 201200640

Matola T., Jablonkai I. 2007. Safening efficacy of halogenated acetals, ketals and amides and relationship between the structure and effect on glutathione and glutathione S-transferases in maize. Cron Protection, 26 (3): 278-284 http://dx.doi.org/10.1016/j.cropro.2005.07.015

Parsa M., Aliverdi A., Hammami H. 2013. Etfect of the recommended and optimized doses of haloxyfop-P-methyl or imazethapyr on soybean-Bradyrhizobium japonicum symbiosis. Industrial Crops and Products, 50 (10): 197-202 http://dx.doi.org/10.1016/j.indcrop.2013.07.019

Requejo R., Tena M. 2012. Influence of glutathione chemical effectors in the response of maize to arsenic exposure. Journal of Plant Physiology, 169 (7): 649-656 http://dx.doi.org/10.1016/j.jplph.2012.01.016

Riechers D. E., Kreuz K., Zhang Q. 2010. Detoxification without intoxication: herbicide safeners activate plant defence gene expression. Plant Physiology, 153 (1): 3-13 http://dx.doi.org/10.1104/pp.110.153601

Rushing J. B., Baldwin B. S., Taylor A. G., Owens V. N., Fike J. H., Moore K. J. 2013. Seed safening from herbicidal injury in switchgrass establishment. Crop Science. 53 (4): 1650-1657 $\mathrm{http} / / / \mathrm{dx}$. doi.org/10.2135/cropsci2013.01.0050

Scarponi L., Quagliarini E., Del Buono D. 2006. Induction of wheat and maize glutathione S-transferase by some herbicide safeners and their effect on enzyme activity against butachlor and terbuthylazine. Pest Management Science. 62 (10): 927-932 http://dx.doi.org/10.1002/ps. 1258

WRB. 2014. World reference base for soil resources 2014 . International soil classification system for naming soils and creating legends for soil maps. World Soil Resources Reports No. 106. FAO, Rome, p. 97

Zhao L. X., Fu Y., Gao S., Xing Z. Y., Wei L. N., Ye F. 2014. Protective responses induced by 3-dichloroacetyl oxazolidine safeners in maize (Zea mays). International Journal of Agriculture and Biology, 16 (6): 1204-1208

\title{
Apsauginis 3-dichloroacetilo oksazolidino chiralinių junginių poveikis kukurūzams nuo pažeidimo haloksifopo-P-metilu]
}

\author{
F. Ye, H.-F. Cao, Y. Fu, L.-X. Zhao, S. Gao \\ Kinijos Šiaurès Rytų žemės ūkio universiteto Tiksliujų mokslų kolegija
}

\section{Santrauka}

Herbicidų apsauginès medžiagos, sudarančios atskirą ịvairių chemikalų grupę, yra svarbi priemonè, naudojama augalus apsaugoti nuo pažeidimo herbicidais. Siekiant sumažinti haloksifopo-P-metilo pernašos žalą jautriems augalams, tirtas poveikis keturių apsauginių medžiagų - R-28725, 3-dichloroacetilo oksazolidino ir jo dviejų optinių izomerų. Fiziologiniai ir biocheminiai tyrimai buvo atlikti laboratorinèmis sąlygomis Šiaurès Rytų žemès ūkio universitete. Tyrimo metu sẻklos buvo apdorotos apsaugine medžiaga, o dirvožemis - haloksifopo-P-metilu. Séklos, apdorotos apsauginėmis medžiagomis, buvo saugios nuo haloksifopo-P-metilo. Tyrimo metu nustatyta teigiama koreliacija tarp augimo lygio ir endogeninio glutationo (GSH) kiekio bei glutationo S-transferazès (GST) veiklos. GSH kiekio bei GST aktyvumo padidejimas ir GST panašumas i 1-chloro-2,4-dinitrobenzeną (CDNB) kukurūzuose, apdorotuose R-28725, buvo maksimalūs. Tačiau dèl herbicido detoksikacijos acetil-CoAcarboksilazès (ACC) aktyvumo padidejimas kukurūzuose neįvyko.

Reikšminiai žodžiai: glutationo S-transferazès aktyvumas, glutationo S-transferazès panašumas, haloksifop-Pmetilas, 3-dichloroacetilo oksazolidinas.

Please use the following format when citing the article:

Ye F., Cao H.-F., Fu Y., Zhao L.-X., Gao S. 2016. The safener effect of chiral derivatives of 3-dichloroacetyl oxazolidine against haloxyfop-P-methyl-induced toxicity in maize. Zemdirbyste-Agriculture, 103 (1): 29-34 DOI 10.13080/z-a.2016.103.004 